\title{
The Socio Cultural Background as Semantic Implication: How to Identify it Within a Literary Text
}

\author{
Ledia Kazazi \\ PhD Candidate \\ "Aleksandër Xhuvani” University, Elbasan, Albania \\ lediakazazi@gmail.com
}

\section{Doi:10.5901/jesr.2013.v3n7p398}

\begin{abstract}
All linguists and literary critics are aware of the complexity of a literary text. The complete interpretation and understanding of such a text definitely requires some extra linguistic knowledge. According to the Reception Theory, a crucial element that defines the reception of the meaning of a text is the socio cultural background of the text itself. This article considers the socio cultural background as a kind of semantic implication. It aims at presenting a theoretical approach of this theory as well as introducing some ideas on how to identify it. It will also explain and analyze some very important notions relevant to the theory, such as the notion of the text, meaning, semantics etc. The examples provided to support the theory are taken from the work in prose of Martin Camaj. Camaj is well known for the vivid descriptions and representations of the northern Albanian lifestyle and costumes. In order to completely embrace the meaning of his text, the reader must firstly identify and analyze the socio cultural background.
\end{abstract}

Keywords: implication, semantics, text, socio cultural background, entailment

\section{Introduction}

The origin of the artwork is art. Art is real in the artwork. (Heidegger, 2000, p. 19) Literature is considered as being a work of art and as such it has the duty to express the truth. However, a literary text is far more complex than that. Which is the truth of a literary text, the one stated by the author or the one perceived by the reader? The text is destined to be read and only after being read does it acquire its real meaning. The meaning may be explicit, easily understood by everyone, or implicit, impossible to be embraced by the reader. The implicit meaning of a text is known in modern linguistic as semantic entailment. That suggests that the reader must firstly acquire some extralinguistic, socio cultural background knowledge in order to fully master the understanding of text. The text is a linguistic entity that carries multiple interpretations. The Reception Theory considers the reader as the main actor in the realization of the text's aim. However there is a bridge that links the author and the reader and that is the identification of the implied meaning through the analysis of the socio cultural aspects of the work.

\section{What is a "text"?}

The text is generally defined as a linguistic entity that provides communication, whether in a spoken or written form. Linguistics has a different view on this category. From the linguistic point of view, a text is an entity made up of linguistic signs and characterized by cohesion and coherence. So, according to Werlich a text is an extended structure of syntactic units such as words, groups, and clauses and textual units that is marked by both coherence among the elements and completion.... A non-text consists of random sequences of linguistic units such as sentences, paragraphs, or sections in any temporal and/or spatial extension. (Werlich, 1976, p. 23) De Beaugrande and Dressler define the text as a naturally occurring manifestation of language, i.e. as a communicative language event in a context. The "surface text" is the set of expressions actually used; these expressions make some knowledge "explicit", while other knowledge remains "implicit",though still applied during processing. (De Beaugrande, Dressler, 1981, p. 63) The literary text is a specific kind of text. It does not contain one specific meaning but offers a variety of meanings. The perception of different readers may be different and also differ from the aim of the author. 


\section{Reception theory and Hermeneutics}

The reception theory pays great attention to the role of the reader in a process of literary experience. According to Jauss literature is a dialectical process of production and reception (Jauss, 1982, p. 15). He holds the idea that a literary text acquires its real value when the interaction of the author meets the interaction of the public. Another prominent figure in Reception Theory is Iser. He also considers the reader as the main element in the realisation of the meaning of a text. According to him the work is more than the text, for the text only takes on life when it is realized, and furthermore the realization is by no means independent of the individual disposition of the reader...the convergence of text and reader brings the literary work into existence. (Iser, 1974, pp. 274-275) This clearly proves and suggests that literature is a process where reader and text interact with each other and complement each other. This is a hermeneutical approach. According to de Man, hermeneutics is the process directed towards the determination of meaning. He holds the opinion that there are some important extralinguistic factors that contribute to that. (de Man, 1982) Therefore, the notion of hermeneutics is a key element in Reception Theory since the reader's interpretation is part of the literary process. However, in order to completely embrace the meaning of a text the reader must be equipped with some extralingustic background knowledge. This can be difficult and it may not occur in cases when:

- The text in native language involves a temporal distance

- There is an ideological difference between the reader and the text

- The text is translated, thus being produced in a completely different cultural atmosphere. (Teichman, 2010, p. 68)

In these cases the reader is helped by his extralingustic knowledge such as the historical and socio cultural background. This is due to the fact that despite its explicit information, a text carries implicit information too. The later is encoded in between the lines.

\section{The socio cultural entailment}

So, which is the meaning of the word "implicit"? The definition of this word according to the Oxford Dictionary is "suggested though not directly expressed" (Dictionary, 2013). Linguistics uses another term to refer to implications: entailment. This is a term derived from formal logic and now is used as part of study of semantics. Lyons gives a logical definition of entailment "a relation that holds between $\mathrm{P}$ and $\mathrm{Q}$ where $\mathrm{P}$ and $\mathrm{Q}$ are variables standing for propositions such that if the truth of Q necessarily follows from the truth of P, then P entails Q". (Lyons, 1977, p. 85) What we are interested in is the socio cultural entailment. This category involves an extralinguistic, cultural context that is crucial for the understanding of a text. When defining the elements of meaning Lyons states that there exist descriptive, social and expressive elements of meaning (Lyons, 1997, p. 50). With this division, he points out how these social factor influence meaning.

The socio cultural entailment belongs within the domain of semantics, because it is an element that defines meaning. It involves a complex knowledge of the world and is mirrored inside the semantics of the linguistic items of the text. The presence of entailments can be discovered in different ways:

- The socio cultural entailment is part of the word lexemes.

- The socio cultural entailment may be separated or connected to the referential (connotative) meaning.

- Entailment is a result of the blending of socio cultural and denotative aspects.

- Linguistic entailment is realized within the text. The relations of lexemes form the lexical field.

- The activation of a lexeme in the conscience of the reader is determined by the socio cultural experience. (Pohl, 1991, p. 243)

However, it is very difficult to scientifically find out which part of the lexicon carries semantic entailment. That is why it is placed in between the linguistic knowledge and the extralinguistic one. It is part of a general empirical knowledge but on the other hand it is closely connected with language. Thus, the socio cultural entailment may be defined as an essential part of the referential meaning.

\section{Socio cultural entailment in Camaj's "Dranja"}

Now, let's focus on the actualization of the theories about the socio cultural entailment in the analysis of a literary text. The chosen text is "Dranja" written by the Albanian author Martin Camaj. Camaj is well known for the vivid portrayals of the Albanian life and culture which he achieves by an excellent description of characters and setting. There are various 
socio cultural elements in his texts and knowing and identifying those elements is crucial for the complete understanding of the texts. This is also the case of "Dranja". The title itself encodes some implicit information. "Dranja" is the name of a female turtle, which at the same time happens to be the name of a beautiful girl from Dukagjin, the author's birthplace, as well as a dialectical form of the noun "drande", meaning "rose". Thus the title could be read as "the woman- turtle" or "the turtle - rose". (Pipa, 1991, p. 142) This work is considered to be an autobiographical account of the author's life with the turtle being his alter ego. When analyzing the text of Camaj from the linguistic point of view, we cannot pass it on without noticing some orthographic mistakes. This may interpreted as a sign of seeking for imperfection, according to what the author states at the very beginning: "on the destiny of a non perfect being" (Camaj, 1981, p. 4) Thus, there are words such as: i panjoftum (unknown) and njohë (known); ngritem (arise) instead of ngrihem; ndoj (some) instead of ndonji and there is a word that is impossible to be found in any Albanian language dictionary: bulshanë. In order to understand the meaning of these words the reader must not only be a fluent speaker of the Albanian language but he must also speak the Gheg dialect.

Even though there is not a specific lexical category that encodes semantic entailment useful for embracing the meaning of the text, there are some constituents that tend to carry connotations embodied with implicit information. These generally denote objects of the material culture and the Albanian tradition. So, there is great usage of phraseology, mainly oral idioms that have been elaborated by the author and completely melted within the text. There are idioms that are used to describe physical appearance such as: bukuria e lypun tepër i del për hundësh; vajzë picak, e marrshme; behavior such as: si zorra në prush; u suell rrakel si i dekun; fle si kali në kambë; su bie hana e dielli kurrë mbrapsht; and other categories such as: uji lane edhe murtajën; u këllat në ujë; here të ambla, here të njelme; ora e gurit tone; lëpushka e laknës së huej; si keza nuses etc.

In order to give a clear portrayal of the characters the author has made extensive usage of literary and stylistic figures. Their main aim is to provide specific information on the characters, mainly, through the comparison with elements of nature, animals and sounds such as: si pela ime Dranja, e unë mbi të kaluer; të ndulkuna mirë e mirë në dushk; se mjellaza e ndritun e rrezeve; fjala e tij vetëm tinguj ndër dhamë të thyem për të mos lanë kund hije në rrasë; ngjau si me qenë gur në syte e çdo kalimtari; nuk ishte edhacake por dhease; vetëdija ashtë një shkëputje e dhemb si ndamja e mishit prej ashtit; nuk ka hyllësi në qiell me emnin breshkë; kur një brezni apo popull i tanë humb drejtimin, ska zot që e ndih; si vargje me masa të përkryeme safike etc.

Another interesting aspect of the lexicon of Camaj in "Dranja" is the presence of some original words that might be a creation of Camaj or part of the oral speech of Northern Albania. Inside the text they acquire a stylistic and emotional value that goes beyond the art of speech. Words such as: dushkaje, mjellaza, shkundullima, lagshtima, krekcare, rangatore, brashkanit, mendulla, paduresa, rrakel, ngulshueshëm, brakesha, kashnjet, bujena, buknor, shqimthi, breshkujza, kryeshpatuke, sherrie, skapullue, karajeli, lotore, gizhla, gazakeqas, jeh, pezulin, lemazë etc, give a great contribution to the artistic enrichment of the text and to its complexity as well.

\section{Conclusions}

A text may be considered as an endless source of information about the culture of the society of the language in which it was written. This article was focused on the importance of the socio cultural background the interpretation of a literary text. It pointed out that it is a kind of semantic entailment that carries referential meaning. There is implicit information encoded within the lines of a text. Even though there isn't a specific lexical category where it might be traced it is present in a lot of idiomatic expressions, as well as stylistic figures. Camaj is a writer whose work is full of entailments. Their identification is crucial for the interpretation and understanding of his work, which are like an encyclopedia about the North of Albania. In order to completely embrace the meaning of his texts the reader must firstly acquire some background knowledge about the Albanian customs and traditions. Only when doing so will he be able to master the text.

\section{References}

Camaj, M. (1981). Dranja. Roma: Tipografia Detti .

De Man, P. (1982). Introduction. In H. R. Jauss, Toward an Aesthetic of Reception. Minneapolis: University of Minnesota Press.

Dictionary, O. (2013). oxford dictionaries. Retrieved June 25, 2013, from oxforddictionaries.com: http://oxforddictionaries.com /definition/english/implicit

Heidegger, M. (2000). The origin of the work of art. In M. Heidegger, Off the beaten track (pp. 1-56 ). Cambridge: Cambridge University Press.

Iser, W. (1974). The Implied Reader: Patterns of Communication in Prose Fiction from Bunyan to Beckett. Baltimore and London: The 
John Hopkins University Press.

Jauss, H. R. (1982). Toward an Aesthetic of Reception. Minneapolis: University of Minesota Press.

Lyons, J. (1977). New Horizons in Linguistics. Harmondsworth: Penguin Books.

Lyons, J. (1997). Semantics. Cambridge: Cambridge University Press.

Pipa, A. (1991). Contemporary Albanian Literature. New York: Colombia University Press.

Pohl, I. (1991). Indentifikation und Wirkungsweise der semantischen Implikation soziokulturellen Hintergrundwissens. In I. P. V. G Bartels, Studien zyr Semantik (p. 243). Berlin, Bern, New York, Paris, Wien: Sprache, System und Tatigkeit.

Robert-Alain De Beaugrande, Wolfgang Ulrich Dressler. (1981). Introduction to text linguistics. London; New York: Longman.

Teichman, E. (2010). Socialpragmatike Ligjerimore. In E. Teichman, Hapa ne Universin e Ligjerimit (pp. 63-68). Tirane: Marin Barleti. Werlich, E. (1976). A text grammar of English. Heidelberg: Quelle \& Meyer. 